\title{
Filling arms production data gaps: South America as a case in point
}

\section{Diego Lopes da Silva}

Diego Lopes da Silva is Associate Researcher with the Stockholm International Peace Research Institute, Stockholm, Sweden, and post-doc researcher at the Institute for Public Policy and International Relations, São Paulo State University, São Paulo, Brazil. He may be reached at diego.lopes.silva@outlook.com.

\section{Abstract}

In this article I argue that the data collection methods and procedures behind the Stockholm International Peace Research Institute's (SIPRI) global arms trade database can also be used to approximate domestic purchases of local production of major conventional arms. The total output of domestic arms industries would then be the sum of what is domestically retained (procured) plus arms exports, if any. The feasibility of this idea is tested by presenting new data on domestic arms production for five South American countries (Argentina, Brazil, Chile, Colombia, and Venezuela) between 1960 and 2015. The results show the critical role government purchases play in maintaining domestic arms industries.

$\mathrm{O}$ ne of the main research challenges in defense and peace economics concerns data availability. For example, states may choose not to disclose information on arms production or trade as this might hinder deterrence and impair their strategic position. This assumes that states do have full information, but the lack of specialized local bureaucracies in maintaining national statistics may in fact contribute to poor data to begin with. Despite its crucial importance, the literature has only occasionally discussed issues of data availability and accuracy. ${ }^{1}$

While challenging, there are important efforts to amend the opacity in military affairs and associated data. In particular, the Stockholm International Peace Research Institute (SIPRI) stands out as the leading institution providing data on arms industries, trade, and military expenditure. Regarded by many as the most authoritative source of information for defense and peace economics research, its data are widely used in the literature. Although providing data at very high standards of quality, SIPRI's work still has significant gaps. In this article, I discuss one, if perhaps not the main, shortcoming of SIPRI's databases, namely the lack of data on domestic arms production and procurement. I argue that collecting or imputing such data is feasible by using the same measurement methodology SIPRI currently applies to build its arms trade database - the Trend Indicator Value (TIV). Plausible estimates of overall national arms industrial output can then be achieved. To illustrate feasibility, I present a new dataset of arms production for Argentina, Brazil, Chile, Colombia, and Venezuela, 1960 to $2015 .^{2}$

This article is organized as follows. In the first section, I discuss SIPRI's arms industry and arms trade databases, their uses in the literature, and their limits. A review of the main empirical attempts to amend the absence of domestic procurement data is also provided. In a second section, I make a case that, using SIPRI's arms transfer methodology, it is possible to gather data on domestic arms purchases potentially going back to 1950 , the starting year of SIPRI's database. The third section presents and discusses the dataset on South America's arms production, stressing its contributions and limitations.

SIPRI's data on arms industry and trade: Contributions and limitations

SIPRI's arms trade database records all transfers of major conventional weapons from 1950 to the most recent full calendar year. Extant studies on arms production and arms transfers much rely on SIPRI's records. ${ }^{3}$ Likewise, SIPRI's arms industry database has proven to be a valuable resource. The institute provides annual data on the top-100 largest arms producing and military services firms, recording market shares, profits, total sales, and levels of employment. ${ }^{4}$ The arms industry database has been used, for example, to track the process of firm consolidation taking place since the late 1980s. ${ }^{5}$

Although highly valuable, SIPRI's data have some critical gaps. In particular, none of the databases provide figures for domestic arms procurement. By accounting for international transfers only, the arms transfers database possibly misses a significant part of the industry's output. Similarly, the top-100 arms industry database provides no information about where production takes place, so that the locally produced and purchased share is not known. Domestic procurement data, were it available, could allow for a more accurate assessment of the determinants of arms imports, the role played by foreign markets, and supplier dependency. ${ }^{6}$ 
This data gap, however, must be contextualized. When created, in 1989, the arms industry database aimed at understanding how the changing international environment would affect arms companies and their relationship with the state. Addressing issues of domestic arms procurement or import dependence was beyond its initial scope. SIPRI certainly excelled at this principal task; notwithstanding, as research agendas shift and more data become available, other dimensions of the arms industry must be explored.

Empirical efforts have tried to amend or bypass these data limitations. Bove and Cavatorta (2012) estimate the share of domestic procurement in military expenditure by equaling it to domestic arms production plus arms imports minus arms exports. Smith and Tasiran (2010) adopt a random coefficient approach to account for the effects of unobserved domestic production capability on arms imports propensity. Yesilyurt, et al. (2014) seek to remedy the same shortcoming by using the International Standard Industrial Classification (ISIC) code 2927 for armaments and ammunition as a database for arms industry output. Nonetheless, the figures provided by ISIC suffer from various weaknesses such as the limited number of weapon types included. Moreover, the regular revision of ISIC data classification to reflect technological and industrial changes compromises data consistency for long-term analysis. These concerns are worsened in that the category of weapons and ammunition does not cover all arms production, excluding platforms for example. Considering the lack of long-span data on arms production, Yesilyurt, et al. (2014) provide a relatively short panel data covering 15 countries between 1997 and 2002 .

\section{The case for domestic procurement data}

Domestic procurement data are in nearly ubiquitous demand in the literature. By providing it, SIPRI would further assist researchers to improve their empirical investigations and thus increase our understanding of the arms industry. However, this is no easy task as it may demand new measurement methods, data sources, and human resources. Albeit challenging, the task is not impossible, and considering the potential benefits, it is certainly worthwhile.

SIPRI's arms industry database, in its current form, has some limitations that may hamper efforts to account for domestic procurement or national arms production output. The data collection process for this database relies mainly on firm's annual reports. Publicly available information on financial and employment data on the arms industry worldwide is limited, and the quantity and quality of the information provided vary widely. For purposes of consistency, SIPRI focuses on a minimum common denominator, forgoing any additional information that is not available across reports. Consequently,
This article argues that collecting or imputing domestic arms production data worldwide is feasible by using the same measurement methodology the Stockholm International Peace Research Institute (SIPRI) currently applies to build its global arms trade database - the Trend Indicator Value (TIV). Plausible estimates of overall national arms industrial output can then be achieved. To illustrate the feasibility, the article presents a new dataset of arms production for Argentina, Brazil, Chile, Colombia, and Venezuela covering the years 1960 to 2015.

the arms industry top-100 list does not specify, for example, where the production takes place as data are not provided consistently among firms. Without this information, it is not possible to build national output time-series.

Another shortcoming of the arms industry database is its regional bias. By sorting the database based on sheer performance measures, it excludes smaller and incipient arms industries often located in developing countries. Hence, the arms industry database is useful insofar as it addresses production in economically developed areas, such as Western Europe and North America. As discussed later on, a revival in arms production in South America has taken place over the past decade or so; however, due to the criteria of SIPRI's arms industry database, this revival is largely ignored even though several prominent arms companies have conducted businesses in that region, such as BAE Systems and Saab for example. This bias is unfortunate as the study of the determinants of arms production in developing countries is an important strand in the literature. ${ }^{7}$

The arms trade database itself may provide a feasible and efficient solution to this data conundrum. SIPRI uses a standard measurement unit to track international arms transfers, the Trend Indicator Value (TIV). TIVs are based on the known unit production costs of a core set of weapons. They represent the transfer of military resources rather than of financial values. Weapons for which the production costs are unknown are compared with core weapons based on size and performance characteristics. Intended as a standard unit to allow for the measurement of arms flow trends to countries and regions over time, these TIVs could also be used to record domestic procurement as some of the primary sources used by SIPRI to collect data for arms transfers also contain records of domestic purchases. Examples includes Jane's All the World's Aircraft, Jane's All World's Fighting Ships, and Conway's All the World's Aircraft. These publications offer annually updated military inventories, including locally produced equipment. Once identified, this equipment knowledge could be converted into TIVs, thus giving a measure of local arms transfer. By tracking domestic procurement, an estimate of total arms 
production can be achieved, adding domestic purchases to exports. The use of the same measurement method to account for domestic purchases is an efficient way to expand SIPRI's databases, fills a critical data gap, and compensates for the regional bias of the arms industry database. This is not to say an expansion is effortless; however, it is an efficient solution as it would employ a method already in use. In the following section, I present new data on arms production in South America using the method discussed above.

\section{Arms production in South America}

Scholarly work on arms production in South America divides into two waves. The first analyzed the performance of arms industries during the 1970s and 1980s, addressing mainly the cases of Argentina, Brazil, and Chile. Due to the significant size it achieved by the 1980s, Brazil's arms industry was the most widely studied. ${ }^{8}$ This strand of the literature also proposed a number of hypothesis regarding the subsequent failure of these industries. In the Brazilian case, for instance, the steep fall in arms exports following the end of the Iran-Iraq war of the 1980s is identified as one of the main reasons for the subsequent industry's crisis and demise. On this matter, there is broad a consensus in the literature. Lock (1986, p. 81), for example, asserts that as exports were Brazil's main arms production driver, eventual domestic financial constraints did not permit the continuance of large domestic procurement.

During the 1990s, military spending in the region was severely curtailed. As regional arms industries were dismantled - several arms firms went bankrupt or else were privatized-academic interest faded away. Interest was renewed when, by the mid-2000s, a worldwide commodity boom lifted economic conditions and budget constraints in South America and allowed governments to allocate more funds to military projects and investments. The recent wave of scholarly work has mainly focused on the political drivers behind this revival. ${ }^{9}$

The bulk of the literature on domestic arms production in South America adopted a qualitative methodological framework. Statistical tools have only seldom been employed. While contributing substantially to our current understanding of the industries, this approach has disregarded quantitative data collection. Its primary focus was placed on policy analysis and decisionmaking processes. Consequently, data on domestic arms production in South America are scattered in the literature. Maldifassi and Abetti (1994) provide estimates of domestic purchases for Argentina, Brazil, and Chile between 1969 and 1988 based on a "minimum cost per soldier" calculation. While clever, the estimates nevertheless are imprecise as their base value relies on an assumption. ${ }^{10}$ More accurate data on domestic arms procurement and arms industry output for South America could provide evidence to corroborate or to refute hypotheses put forward in the literature. For instance, several studies of Brazil's arms industry attribute the crisis of the sector to a loss of foreign markets. But without an assessment of the role played by the domestic market vis-à-vis arms exports, such conclusion might be an extrapolation.

To fill the data gap and illustrate the feasibility of expanding SIPRI's database, I present data on domestic procurement for Argentina, Brazil, Chile, Colombia, and Venezuela between 1960 and 2015. Data were collected from numerous editions of specialized publications in military inventories such as the aforementioned works by Jane's and Conway's. Moreover, SIPRI granted access to its internal database in which some domestic acquisitions are also listed. ${ }^{11}$

The process of building the database follows a two-step routine: identification and valuation. For example, Argentina's Espora class frigates (Meko 140 A16) were built at the Río Santiago Shipyard (Astilleros y Fábricas Navales del Estado, or AFNE) under a license contract with Blohm and Voss signed on 1 August 1979. All frigates were acquired by the Argentine Navy and registered as domestic procurement. Records of the acquisitions were found in the 2016 edition of Jane's All World's Fighting Ships. After identification, purchases are transformed into SIPRI Trend Indicator Values (TIVs). Argentina's 1986 acquisition of the Rosales frigate, for instance, records a TIV of 226.32. By using TIVs to track domestic procurement, an estimate of total arms production can be achieved, adding domestic purchases to exports. Regarding export values, equipment not locally produced or assembled was excluded.

Tables 1 and 2 provide summary measures of the resulting overall dataset. The descriptive statistics indicate interesting aspects of the industry so far unnoticed in the literature. First, the data suggest that the domestic market plays a crucial role in maintaining arms industries in South America: The vast majority of the trade was conducted locally for purposes of domestic arms procurement. While substantial empirical evidence on the importance of exporting arms exists, far less attention has been given to the role played by domestic procurement, a shortcoming that may now be rectified. ${ }^{12}$ Consider the Argentinean case whose arms exports are small, as observed in the literature, ${ }^{13}$ so that the state is the predominant recipient of Argentina's arms industrial output. The domestic market played a similarly overwhelming role in Chile. The importance of foreign markets is higher in Brazil's case but not as much as one would expect. Foreign clients were the main recipient of arms for most of the 1980s, true, but the 
Table 1: Descriptive statistics (Argentina, Brazil, Chile, Colombia, and Venezuela, 1960- 2015)

$\begin{array}{lcccccc} & \text { Argentina } & \text { Brazil } & \text { Chile } & \text { Colombia } & \text { Venezuela } & \text { Mean } \\ \begin{array}{l}\text { Arms } \\ \text { production }\end{array} & 79.3 & 254.6 & 18 & 6.2 & 2.6 & 72.1 \\ \begin{array}{l}\text { Domestic } \\ \text { Procurement }\end{array} & 78.6 & 197.6 & 17.2 & 6.2 & 2.3 & 60.4 \\ \begin{array}{l}\text { Arms } \\ \text { exports }\end{array} & 0.74 & 57 & 0.9 & 0 & 0.3 & 11.8 \\ \begin{array}{l}\text { Arms } \\ \text { imports }\end{array} & 362.8 & 474.7 & 348.7 & 178.7 & 379.5 & 348.9 \\ \begin{array}{l}\text { Military } \\ \text { expenditure }\end{array} & 6,394.8 & 11,208.4 & 2,340.7 & 3,202.9 & 10,629.1 & 6,755.2 \\ \text { GDP } & 0.28 & 1.32 & 0.12 & 0.17 & 0.26 & 0.43\end{array}$

Notes: Arms production, exports, imports and domestic procurement are in millions of TIV dollars at 2015 constant prices. Military expenditure is in millions of 2015 constant dollars, GDP is in trillions of 2015 constant dollars. Unweighted mean. Sources: Arms exports, imports, and military expenditure (SIPRI); GDP(World Bank). Arms production and domestic procurement, author's calculations.

Table 2: Pearson's $R$ correlation matrix

$\begin{array}{lcccccc} & \begin{array}{c}\text { Arms } \\ \text { prod. }\end{array} & \begin{array}{c}\text { Domestic } \\ \text { proc. }\end{array} & \begin{array}{c}\text { Arms } \\ \text { exports }\end{array} & \begin{array}{c}\text { Arms } \\ \text { imports }\end{array} & \begin{array}{c}\text { Military } \\ \text { exp. }\end{array} & \text { GDP } \\ \text { Arms production } & 1 & & & & & \\ \text { Domestic procurement } & 0.97 & 1 & & & & \\ \text { Arms exports } & 0.64 & 0.45 & 1 & & & \\ \text { Arms imports } & 0.27 & 0.28 & 0.10 & 1 & & \\ \text { Military expenditure } & 0.35 & 0.33 & 0.25 & 0.35 & 1 & \\ \text { GDP } & 0.56 & 0.50 & 0.52 & 0.17 & 0.73 & 1\end{array}$

Table 3: Argentina's Espora class (Meko 140 A16)

$\begin{array}{lccc}\text { Name } & \text { (1) } & \text { (2) } & \text { (3) } \\ \text { Espora } & 1980 & 1982 & 1985 \\ \text { Rosales } & 1981 & 1983 & 1986 \\ \text { Spiro } & 1982 & 1983 & 1987 \\ \text { Parker } & 1982 & 1984 & 1990 \\ \text { Robinson } & 1983 & 1985 & 2000 \\ \text { Gomez Roca } & 1983 & 1986 & 2004\end{array}$

Notes: (1) "Laid down" means that the keel has ben laid and marks the beginning of production; (2) "Launched" refers to the moment the ship is actually put in the water; (3) "Commissioned" refers to the time of delivery, i.e., the official acquisition date. Source: Jane's All the World's Fighting Ships (2016).

would significantly increase.

Table 2 correlates total arms production, exports, imports, domestic procurement, military expenditure, and GDP to each other. Arms production has a remarkably high correlation with domestic procurement $(r=0.97)$, and arms exports comes in second place $(r=0.64)$. Interestingly, domestic procurement has a positive correlation with arms imports, possibly suggesting that the industry's

industry was borne out of a local demand shock. This corroborates Kapstein (1991) who stated that contrary to the contention of some analysts at the time, Brazil's arms industry was not established as an export sector from its inception. Instead, its primary goal was to meet the domestic requirements of Brazil's own military forces. Domestic procurement data were also found for Colombia and Venezuela. In their cases, however, no significant revisions of what is currently known about them arise.

As mentioned, in adding exports to domestic procurement one arrives at a total arms production output figure. These data then shed light on the overall size of the arms industry in South America. In Table 1, the figures for total arms production are significantly higher than those for exports alone-72.1 versus 11.8 - indicating that assessments of South America's arms industry based solely on exports, particularly for Argentina, Brazil, and Chile, underestimate its actual size. If this divergence between old and new data were to be found for other countries as well then estimates of arms production output was not sufficient to result in substitution between these two variables. The finding of a positive association between arms production and imports in developing countries is in line with previous empirical studies. ${ }^{14}$ The correlation between arms production and military expenditure $(r=0.35)$ varies among countries. In Argentina, military spending is closely correlated to arms production. But in Brazil arms industry output fell despite growing military spending.

Expanding SIPRI's dataset in this way does not add any new methodological problems as the TIV method already is in place and widely accepted. That said, an expansion would certainly reproduce some of the current shortcomings, mainly the disregard for changes in the production costs of a same equipment. To reuse an example, Argentina's Espora class frigates (Meko 140 A16) were commissioned between 1985 and 2004 (Table 3, Column 3). The construction of the last two frigates, Robinson and Gomez Roca, were to be canceled. However, in 1997 the government decided to resume production plans. During this time span, production costs have 
certainly changed, and most likely risen. ${ }^{15}$ Yet, there is no methodological artifice to include such alteration into TIVs. Trend Indicator Values do change according to the generation of the equipment - newer generations of the same equipment type have higher TIVs - but there are no corrections for production costs of the same weapon in different periods. In our example, the same TIV is assigned to all six frigates. By disregarding changes in production costs for the same weapon, TIVs are underestimated when applying SIPRI's measurement methodology. (In essence, TIVs are minimum estimates of production costs.) Developing a production cost change rate for the same weapon system might amend this deficiency. Of course, collecting data for such estimates might prove challenging, perhaps even infeasible, if done on a large scale.

\section{Conclusion}

Over the years, SIPRI has contributed hugely to the betterment of defense and peace economics research by providing data on the global arms industry and its trade at very high standards. Nevertheless, data gaps remain of which the lack of domestic arms production and domestic procurement data is one example. Without these, a complete assessment of the industry is precluded and important questions, such as the determinants and relative importance of arms production, arms imports, and arms export markets, cannot be fully addressed.

SIPRI's arms trade database could potentially be enlarged to record procurement of locally produced equipment. The Trend Indicator Value (TIV) method can be used to track both international and domestic transfers, thus allowing for a better account of arms industry output. The use of TIVs is an efficient solution as no new methodology would be needed. To illustrate the potential benefit, this article discussed the preparation of a new dataset for domestic arms procurement for Argentina, Brazil, Chile, Colombia, and Venezuela covering 1960-2015. Although more refined methods of statistical estimation are still needed, the initial descriptive statistics alone suggest very large domestic markets for domestic arms production.

Future development of this research could disaggregate domestic procurement by weapon categories to learn whether certain types of equipment are oriented to the internal market. Likewise, using domestic procurement figures in inferential statistical models may further our understanding of the determinants of arms production. For such a task, making headway in data collection is imperative.

\section{Notes}

I am grateful to SIPRI's Arms Transfers and Military Spending Programme staff for the help provided to me while conducting this research. I would also like to thank Nan Tian, Raphael
Camargo Lima, Jonathan Assis, and an anonymous reviewer for comments. The usual disclaimer applies.

1. Data availability: The issue is highlighted in Brzoska (1982), Smith and Tasiran (2005, 2010), and Yesilyurt, et al. (2014) and extensively discussed in Kolodziej (1979), Fei (1979), and Brzoska (1982). Regarding military expenditure data, a recent example is Colgan (2011).

2. Widely used in the literature: Some examples of empirical studies using SIPRI's data are Bitzinger (2003), Smith and Tasiran (2005), Villa and Viggiano (2012), Akerman and Seim (2014), and Kollias, et al. (2017).

3. On arms production and transfers, see, e.g., Brzoska (1999, 2004), Sanjian (1999), Kinsella (2000), Smith and Tasiran (2005, 2010), and Battaglino (2013a).

4. Consistent information can be found for about 125 companies, but only the top-100 are reported and published.

5. See Sköns and Wulf 1(994); Bitzinger (1994, 2003). Dunne (2009) draws heavily on SIPRI's database in his account of arms industry restructuring after the cold war. Another example is Hartley and Sandler's (2003) account of the changes defense firms have been subjected to in the 1990s.

6. On imports, see Smith and Tasiran (2005, 2010). Regarding the role played by foreign markets, see Bitzinger (1994), Sköns and Wulf (1994), and Dunne (2009). Studies on supplier dependency include Smith, Humm, and Fontanel (1985), Kinsella (1998), and Neuman (2006).

7. Seminal studies include Peleg (1980) and Neuman (1984).

8. See Lock (1986), Kapstein (1991), Conca (1997), Costa (1998), and Franko (2014).

9. See, e.g., Perlo-Freeman (2004), Battaglino (2011, 2013b), Franko (2014), and Gouvea (2015).

10. Maldifassi and Abetti (1994) calculate domestic arms production levels based on a Dollars Per Soldier (DPS) metric, computed as the ratio of (defense budget-defense imports) to the number of military personnel. For the 20-year period covered by their study, the minimum DPS value then was assumed to represent the minimum possible expenditure per soldier that would allow the armed forces to operate. The authors assume that when DPS was at its lowest point, defense spending was devoted to arms imports, minimum operational expenses, military personnel salaries, and infrastructure maintenance, with no domestic arms purchases.

11. No claim is made that the database is fully complete. Certainly, there are local purchases for which reliable records were not found. Still, it is likely that the bulk of domestic procurement is accounted for and that remaining purchases are minimal as there are no indications whatsoever that major contracts were signed for which I have no data. For example, Brazil acquired a small number of radars $(2$, if not 1$)$ in the early 2000s for which no reliable data were found regarding the amount. Thus, this purchase is excluded. Such cases are not of sufficient weight (expense) to change the main results, such as 
the role and heft of the domestic market.

12. Notable exceptions include Molas-Gallart (1998), Hall, Markowski, and Thomson (1998), and Markowski and Hall (1998).

13. For example, Moraes (2011).

14. See, e.g., Kinsella (2000).

15. Kirkpatrick $(1995,2004)$ discusses the upward trend in arms production costs.

\section{References}

Akerman, A., and A. Larsson Seim. 2014. "The Global Arms Trade Network 1950-2007." Journal of Comparative Economics. Vol. 42, No. 3, pp. 535-51. https://doi.org/10.1016/j.jce.2014.03.001

Battaglino, J. 2011. “Auge, Caída y Retorno de La Defensa En La Argentina." Foreign Affairs Latinoamérica. Vol. 13, No. 1, pp. 32-39.

Battaglino, J. 2013a. "The Determinants of Arms Spending in South America." Journal of Politics in Latin America. Vol. 5, No. 2, pp. 71-103.

Battaglino, J. 2013b. "The Politics of Defense Revival in Argentina." Defense and Security Analysis. Vol. 29, No. 1, pp. $3-15$.

https://doi.org/10.1080/14751798.2013.760251

Bitzinger, R.A. 1994. "The Globalization of the Arms Industry: The Next Proliferation Challenge." International Security. Vol. 19, No. 2, pp. 170-198. https://doi.org/10.2307/2539199

Bitzinger, R.A., ed. 2003. Towards a Brave New Arms Industry. London: Routledge.

Bove, V. and E. Cavatorta. 2012. "From Conscription to Volunteers: Budget Shares in Nato Defence Spending." Defence and Peace Economics. Vol. 23, No. 3, pp. 273-288. https://doi.org/10.1080/10242694.2011.563973

Brzoska, M. 1982. “Arms Transfer Data Sources.” Journal of Conflict Resolution. Vol. 26, No. 1, pp. 77-108. https://doi.org/10.1177/0022002782026001003

Brzoska, M. 1999. "Economic Factors Shaping Arms Production in Less Industrialized Countries." Defence and Peace Economics. Vol. 10, No. 2, pp. 139-169. https://doi.org/10.1080/10430719908404921

Brzoska, M. 2004. "The Economics of Arms Imports after the End of the Cold War." Defence and Peace Economics. Vol. 15, No. 2, pp. 111-123. https://doi.org/10.1080/1024269032000110496

Colgan, J.D. 2011. "Venezuela and Military Expenditure Data." Journal of Peace Research. Vol. 48, No. 4, pp. 547-556. https://doi.org/10.1177/0022343311406156

Conca, K. 1997. Manufacturing Insecurity: The Rise and Fall of Brazil's Military-Industrial Complex. London: Lynne Rienner.

Costa, N.F. da. 1998. "A Indústria Brasileira de Material de Defesa: Principais Óbices.” Revista Da Escola Superior de
Guerra. Vol. 13, No. 37, pp. 160-202.

Dunne, J.P. 2009. "Developments in the Global Arms Industry from the End of the Cold War to the Mid-2000's," pp. 13-37 in R.A. Bitzinger, ed. The Modern Defense Industry: Political, Economic, and Technological Issues. Santa Barbara: Praeger.

Fei, E.T. 1979. "Understanding Arms Transfers and Military Expenditures: Data Problems," pp. 37-48 in S.G. Neuman and R. Harkavy, eds. Arms Transfers in the Modern World. New York: Praeger.

Franko, P.M. 2014. "The Defense Acquisition Trilemma: The Case of Brazil.” Energy. No. 262, pp. 1-12.

Gouvea, R. 2015. "Brazil's New Defense Paradigm.” Defense and Security Analysis. Vol. 31, No. 2, pp. 137-151. https://doi.org/10.1080/14751798.2015.1038452

Hall, P., S. Markowski, and D. Thomson. 1998. "Defence Procurement and Domestic Industry: The Australian Experience." Defence and Peace Economics. Vol. 9, Nos. $1-2$, pp. 137-165.

https://doi.org/10.1080/10430719808404898

Hartley, K., and T. Sandler. 2003. "The Future of the Defence Firm.” Kyklos. Vol. 56, No. 3, pp. 361-380. https://doi.org/10.1046/j.0023-5962.2003.00225.x

Kapstein, E.B. 1991. "The Brazilian Defense Industry and the International System.” Political Science Quarterly. Vol. 105, No. 4, pp. 579-596. https://doi.org/10.2307/2150936

Kinsella, D. 1998. "Arms Transfer Dependence and Foreign Policy Conflict." Journal of Peace Research. Vol. 35, No. 1, pp. 7-23. https://doi.org/10.1177/0022343398035001002

Kinsella, D. 2000. "Arms Production in the Third Tier: An Analysis of Opportunity and Willingness." International Interactions. Vol. 26, No. 3, pp. 253-286. https://doi.org/10.1080/03050620008434968

Kirkpatrick, D.L.I. 1995. "The Rising Unit Cost of Defence Equipment: The Reasons and the Results." Defence and Peace Economics. Vol. 6, No. 4, pp. 263-288. https://doi.org/10.1080/10430719508404831

Kirkpatrick, D.L.I. 2004. "Trends in the Costs of Weapon Systems and the Consequences." Defence and Peace Economics. Vol. 15, No. 3, pp. 259-273. https://doi.org/10.1080/1024269032000123203

Kollias, C., S.M. Paleologou, P. Tzeremes, and N. Tzeremes. 2017. "Defence Expenditure and Economic Growth in Latin American Countries: Evidence from Linear and Nonlinear Causality Tests." Latin American Economic Review. Vol. 26, No. 1, pp. 1-25. https://doi.org/10.1007/s40503-017-0039-4

Kolodziej, E.A. 1979. "Measuring French Arms Transfers: A Problem of Sources and Some Sources of Problems with ACDA Data." Journal of Conflict Resolution. Vol. 23, No. 2, pp. $195-227$. https://doi.org/10.1177/002200277902300201

Lock, P. 1986. "Brazil: Arms for Export," pp. 79-104 in P. Lock, M. Brzoska, and T. Ohlson, eds. Arms Production in 
the Third World. London: Taylor \& Francis.

Maldifassi, J.O., and P. Abetti. 1994. Defense Industries in Latin American Countries: Argentina, Brazil, and Chile. Westport: Praeger.

Markowski, S., and P. Hall. 1998. "Challenges of Defence Procurement." Defence and Peace Economics. Vol. 9, Nos. $1-2$, pp. 3-37. https://doi.org/10.1080/10430719808404892

Molas-Gallart, J. 1998. "Defence Procurement as an Industrial Policy Tool: The Spanish Experience." Defence and Peace Economics. Vol. 9, Nos. 1-2, pp. 63-81. https://doi.org/10.1080/10430719808404894

Moraes, R.F. de. 2011. "A Indústria de Defesa Na Argentina." Boletim de Economia e Política Internacional. No. 6, pp. 49-61.

Neuman, S.G. 1984. "International Stratification and Third World Military Industries." International Organization. Vol. 38, No. 1, pp. 167-197. https://doi.org/10.1017/S0020818300004306

Neuman, S.G. 2006. "Defense Industries and Global Dependency." Orbis. Vol. 50, No. 3, pp. 429-451. https://doi.org/10.1016/j.orbis.2006.04.004

Peleg, I. 1980. "Military Production in Third World Countries: A Political Study," pp. 209-230 in P. McGowan and E. Kegley, eds. Threats, Weapons, and Foreign Policy. Beverly Hills: Sage.

Perlo-Freeman, S. 2004. "Offsets and the Development of the Brazilian Arms Industry," pp. 185-200 in J. Brauer and J.P. Dunne, eds. Arms Trade and Economic Development: Theory, Policy, and Cases in Arms Trade Offsets. London: Routledge. https://doi.org/10.4324/9780203392300_chapter_13

Sanjian, G.S. 1999. "Promoting Stability or Instability? Arms Transfers and Regional Rivalries,1950-1991." International Studies Quarterly. Vol. 43, No. 4, pp. 641-670. https://doi.org/10.1111/0020-8833.00140

Sköns, E., and H. Wulf. 1994. "The Internationalization of the Arms Industry." The Annals of the American Academy of Political and Social Science. Vol. 535, pp. 43-57. https://doi.org/10.1177/0002716294535001004

Smith, R.P, A. Humm, and J. Fontanel. 1985. "The Economics of Exporting Arms." Journal of Peace Research. Vol. 22, No. 3, pp. 239-247. https://doi.org/10.1177/002234338502200305

Smith, R.P., and A. Tasiran. 2005. "The Demand for Arms Imports." Journal of Peace Research. Vol. 42, No. 2, pp. $167-181$. https://doi.org/10.1177/0022343305050689

Smith, R.P., and A. Tasiran. 2010. "Random Coefficients Models of Arms Imports." Economic Modelling. Vol. 27, No. 6, pp. 1522-1528. https://doi.org/10.1016/j.econmod.2010.07.017

Villa, R.D., and J.Viggiano. 2012. "Trends in South American Weapons Purchases at the Beginning of the New Millennium." Revista Brasileira de Política Internacional.
Vol. 55, No. 2, pp. 28-47. https://doi.org/10.1590/S0034-73292012000200003

Yesilyurt, F., B. Güloglu, E. Yesilyurt, and Ş. Sezgin. 2014. "The Determinants of Arms Production." Defence and Peace Economics. Vol. 25, No. 2, pp. 205-211. https://doi.org/10.1080/10242694.2013.804670 